\title{
A social work study on women's tendency on reading Persian novels
}

\author{
Ome Leila Lashkari*
}

MA of Women Study, Baft Branch, Islamic Azad University, School of Humanities, Departement of women studies, Baft, Iran

\begin{tabular}{|c|c|}
\hline C H R O N I C L E & A B S T RACT \\
\hline $\begin{array}{l}\text { Article history: } \\
\text { Received January 22, } 2013 \\
\text { Received in revised format } \\
26 \text { April } 2013 \\
\text { Accepted } 20 \text { May } 2013 \\
\text { Available online } \\
\text { May } 262013 \\
\text { Keywords: } \\
\text { Social skills } \\
\text { Women } \\
\text { Persian Novels }\end{array}$ & $\begin{array}{l}\text { This paper presents a social work study to find out why some Iranian women are interested in } \\
\text { reading Persian novels in city of Tehran, Iran. The proposed study designed a questionnaire and } \\
\text { distributed it among } 150 \text { women who lived in city of Tehran, Iran during the year } 2009 \text {. All } \\
\text { participants were interviewed carefully in order to make sure that they were able to understand } \\
\text { all questions very completely. The results of survey have indicated that there was a meaningful } \\
\text { relationship between women's leisure time and reading Persian novels. There are some positive } \\
\text { relationships between demanding equal opportunity with men and reading novels. The women } \\
\text { who believe the idea of Equality of Men and Women read more novels. In our study, the more } \\
\text { women were interested in reading Persian novels, the less they were interested in becoming } \\
\text { familiar with social issues. In addition, the more women were interested in reading Persian } \\
\text { novels, the more they believed the study could improve their social skills. Those women who } \\
\text { believed in women as hero were more interested in reading novels. Nevertheless, highly } \\
\text { educated women were not very much interested in reading novels. Finally, as women were } \\
\text { aging, they were more interested in reading Persian novels. }\end{array}$ \\
\hline
\end{tabular}

(c) 2013 Growing Science Ltd. All rights reserved.

\section{Introduction}

During the past few years, there has been growing trends on reading novel among Iranian women. These days, we see some Persian novels go out of print more frequently and publishers were getting surprised as they see the sales' figures on some of novels they published. The primary question is to find out why some Iranian women are getting so much interested in reading such books and what would be the relationship between reading novels and women's personal characteristics. There are some studies on Persian novels and stories.

According to Ranjbar (2010), during the 60s (solar calendar) 66 novels were published in Iran for the first time. From this collection, the themes of sixteen works were directly impacted by the revolution and the war. In all these works the social, political, cultural, and economic situation, the circumstances of the intellectuals, the merits of the revolution and the war and the disadvantages of

*Corresponding author. Tel : +989125270778

E-mail addresses: lashkari_pnu@yahoo.com (O. L. Lashkari) 
the two were investigated. Nineteen writers have taken the opportunity to write about topics which were a bit difficult to deal with before the revolution, such as the risks of freedom seeking, social class debates, economic upheavals, ignorance, poverty, injustice, murder, imprisonment, the harassment of freedom seekers, etc. Ranjbar (2010) considered these novels as those impacted by the revolution. The remaining thirty one novels had not been impacted by the revolution or by the revolutionary atmosphere of the time. In other words, they dealt with topics, which could be dealt with in most governments. Such novels mostly included social and emotional themes.

Zavarzadeh (1968), for instance, presented an overview on the Persian short story since the second world war. Rahimi and Ebrahimi (2012) investigated the stylistic differences between Persian and English novelists in terms of their choices and application of lexical patterns. To answer these kinds of questions, two Persian (The Blind Owl by Sadigh Hedayat and The Patient Stone by Sadigh Chubak) together with two English novels (The Old Man and the Sea by Ernest Hemingway and The Pearl by John Steinbeck) which are enormously popular in contemporary Persian and English literatures were selected as the main source of data. They performed an investigation on 1000-word excerpts of these novels and reported that the difference between Persian and English novelists' choices of lexical patterns was created by the higher number of reiteration as well as the collocation pairs implemented by Persian novelists.

Sojoudi and Zirahi (2009) performed a survey of the tense of Persian verbs in Boofe Koor and Sovashoon within the tense theory of Weinrich. Honarmand (2011) investigated the impact of the modernity discourse on Persian fictions. Nanquette (2011) investigated the genre specificity of novels by Franco-Iranian authors and the challenged that the inevitable effect of the French novelistic tradition present to the authors of this Iranian diaspora. They study explained the use of French as a language of writing imposes certain literary norms and helped create a hybrid genre, which could reflect the diasporic experience.

\section{The proposed study}

This paper presents a social work study to find out why some Iranian women are interested in reading Persian novels in city of Tehran, Iran. The proposed study designed a questionnaire and distributed it among 150 women who lived in city of Tehran, Iran during the year 2009. All participants were interviewed carefully in order to make sure that they were able to understand all questions. The proposed study of this paper considers the following eight hypotheses,

1. There is a relationship between women's leisure time and reading Persian novels.

2. There is a relationship between women's demanding equal opportunity with men and reading Persian novels.

3. There is a relationship between believing the idea of Equality of Men and Women and reading Persian novels.

4. There is a relationship between becoming familiar with social issues and reading Persian novels.

5. There is a relationship between improving social skills and reading Persian novels.

6. There is a relationship between believing that women are hero and reading Persian novels.

7. There is a relationship between educational background and reading Persian novels.

8. There is a relationship between age and reading Persian novels.

Cronbach alphas for three groups of investigations on believing Equality of Men and Women, familiarity on social issues and application of novels are $0.74,0.76$ and 0.92 , respectively. The study 
uses Pearson correlation ratio and Chi-Square tests to examine different hypotheses. Fig. 1 demonstrates personal characteristics of participants,
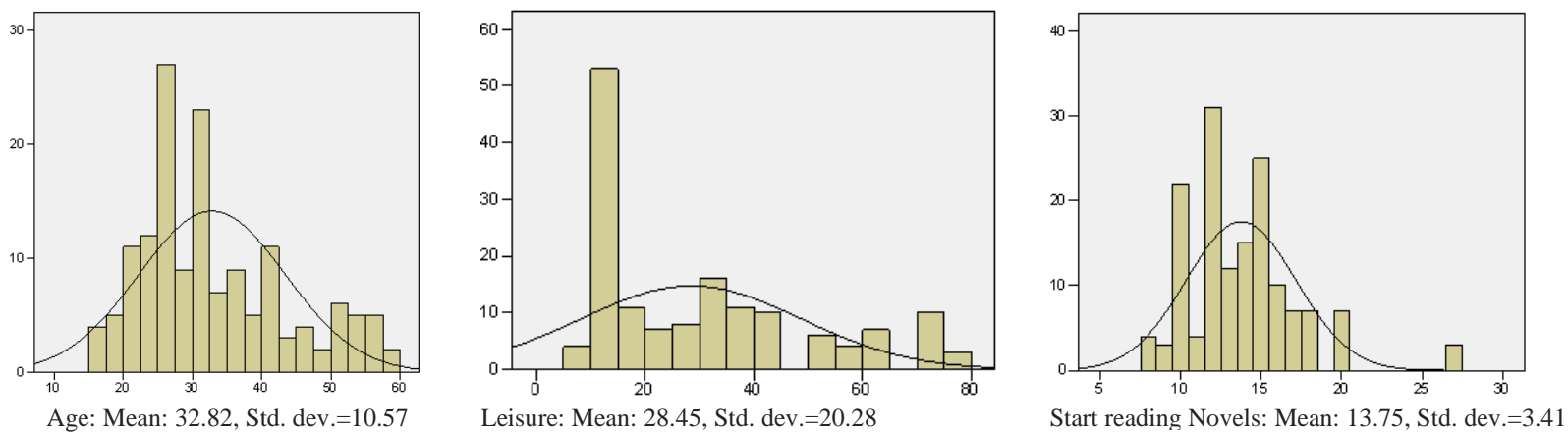

Fig. 1. Personal characteristics of participants in survey

According to Fig. 1, the average age of participants is 32.82 years, while most participants spent their leisure time on reading novels and most of them started reading novels when they were teenagers.

\section{Results}

In this section, we present details of our analysis on testing various hypotheses of this survey.

\subsection{The first hypothesis: Reading novel and leisure}

The first hypothesis of the survey investigates whether there is any relationship between reading novel and their time on leisure. Table 1 demonstrates the results of our survey.

\section{Table 1}

The summary of the survey on relationship between leisure and reading novel

\begin{tabular}{|c|c|c|c|c|}
\hline \multirow{2}{*}{ Reading novel } & \multicolumn{3}{|c|}{ Leisure } & \multirow{2}{*}{ Total } \\
\hline & Little & Average & Very much & \\
\hline Little & $\begin{array}{c}15 \\
15.20 \%\end{array}$ & $\begin{array}{c}3 \\
11.10 \%\end{array}$ & $\begin{array}{c}0 \\
0.00 \%\end{array}$ & $\begin{array}{c}18 \\
12.00 \%\end{array}$ \\
\hline Average & $\begin{array}{c}27 \\
27.30 \%\end{array}$ & $\begin{array}{c}14 \\
51.90 \%\end{array}$ & $\begin{array}{c}3 \\
12.50 \%\end{array}$ & $\begin{array}{c}44 \\
29.30 \%\end{array}$ \\
\hline Very much & $\begin{array}{c}57 \\
57.60 \%\end{array}$ & $\begin{array}{c}10 \\
37.00 \%\end{array}$ & $\begin{array}{c}21 \\
87.50 \%\end{array}$ & $\begin{array}{c}88 \\
58.70 \%\end{array}$ \\
\hline Total & $\begin{array}{c}99 \\
100 \%\end{array}$ & $\begin{array}{c}27 \\
100 \%\end{array}$ & $\begin{array}{c}24 \\
100 \%\end{array}$ & $\begin{array}{c}150 \\
100 \%\end{array}$ \\
\hline
\end{tabular}

Chi-Square $=16.4 \quad \mathrm{df}=4 \quad$ Sig. $=0.000 \quad$ Kendall's tau-b=0.11

As we can observe from the results of Table 1, there are some positive relationship between leisure time and reading novels. In other words, the more women have leisure time, the more they read novels. Therefore, we can confirm the first hypothesis.

\subsection{The second hypothesis: Reading novel and equal opportunity}

The second hypothesis of the survey investigates whether there is any relationship between reading novel and women's demanding equal opportunity with men. Table 2 demonstrates the results of our survey.

Based on the results of Table 2, there are some positive relationships between demanding equal opportunity with men and reading novels. Therefore, we can confirm the second hypothesis. 
Table 2

The summary of the survey on relationship between reading novels and equal opportunity

\begin{tabular}{|c|c|c|c|c|}
\hline \multirow{2}{*}{ Reading novel } & \multicolumn{3}{|c|}{ Equal opportunity } & \multirow{2}{*}{ Total } \\
\hline & Little & Average & Very much & \\
\hline Little & $\begin{array}{c}7 \\
50.00 \%\end{array}$ & $\begin{array}{c}5 \\
12.80 \%\end{array}$ & $\begin{array}{c}6 \\
6.20 \%\end{array}$ & $\begin{array}{c}18 \\
12.00 \%\end{array}$ \\
\hline Average & $\begin{array}{c}0 \\
0.00 \%\end{array}$ & $\begin{array}{c}17 \\
43.60 \%\end{array}$ & $\begin{array}{c}27 \\
27.80 \%\end{array}$ & $\begin{array}{c}44 \\
29.30 \%\end{array}$ \\
\hline Very much & $\begin{array}{c}7 \\
50.00 \%\end{array}$ & $\begin{array}{c}17 \\
43.60 \%\end{array}$ & $\begin{array}{c}64 \\
66.00 \%\end{array}$ & $\begin{array}{c}88 \\
58.70 \%\end{array}$ \\
\hline Total & $\begin{array}{c}99 \\
100 \%\end{array}$ & $\begin{array}{c}14 \\
100 \%\end{array}$ & $\begin{array}{c}39 \\
100 \%\end{array}$ & $\begin{array}{c}97 \\
100 \%\end{array}$ \\
\hline
\end{tabular}

\subsection{The third hypothesis: Reading novel and interest in social affairs}

The third hypothesis of the survey investigates whether there is any relationship between reading novel and women's interest in social affairs. Table 3 shows the results of our survey.

Table 3

The summary of the survey on relationship between interest in social affairs and reading novel

\begin{tabular}{|c|c|c|c|c|}
\hline \multirow{2}{*}{ Reading novel } & \multicolumn{3}{|c|}{ Leisure } & \multirow{2}{*}{ Total } \\
\hline & Little & Average & Very much & \\
\hline Little & $\begin{array}{c}0 \\
0.00 \%\end{array}$ & $\begin{array}{c}15 \\
20.00 \%\end{array}$ & $\begin{array}{c}3 \\
4.90 \%\end{array}$ & $\begin{array}{c}18 \\
12.00 \%\end{array}$ \\
\hline Average & $\begin{array}{c}4 \\
28.60 \%\end{array}$ & $\begin{array}{c}10 \\
13.30 \%\end{array}$ & $\begin{array}{c}30 \\
49.20 \%\end{array}$ & $\begin{array}{c}44 \\
29.30 \%\end{array}$ \\
\hline Very much & $\begin{array}{c}10 \\
71.40 \%\end{array}$ & $\begin{array}{c}50 \\
66.70 \%\end{array}$ & $\begin{array}{c}28 \\
45.90 \%\end{array}$ & $\begin{array}{c}88 \\
58.70 \%\end{array}$ \\
\hline Total & $\begin{array}{c}99 \\
100 \% \\
\end{array}$ & $\begin{array}{c}14 \\
100 \% \\
\end{array}$ & $\begin{array}{c}75 \\
100 \% \\
\end{array}$ & $\begin{array}{c}61 \\
100 \% \\
\end{array}$ \\
\hline
\end{tabular}

The results of Table 3 demonstrate that there are some positive relationship between women's interests in social affairs and reading novels. In other words, the more women are interested in social affairs, the more they read novels. Therefore, we can confirm the third hypothesis.

\subsection{The fourth hypothesis: Reading novel and believing the idea of Equality of Men and Women}

The fourth hypothesis of the survey investigates whether there is any relationship between reading novel and believing the idea of Equality of Men and Women. Table 4 shows the results of our survey.

\section{Table 4}

The summary of the survey on relationship between believing the idea of Equality of Men and Women and reading novel

\begin{tabular}{|c|c|c|c|c|}
\hline \multirow{2}{*}{ Reading novel } & \multicolumn{3}{|c|}{ Leisure } & \multirow{2}{*}{ Total } \\
\hline & Little & Average & Very much & \\
\hline Little & $\begin{array}{c}3 \\
16.70 \%\end{array}$ & $\begin{array}{c}11 \\
25.00 \%\end{array}$ & $\begin{array}{c}14 \\
15.90 \%\end{array}$ & $\begin{array}{c}28 \\
18.70 \%\end{array}$ \\
\hline Average & $\begin{array}{c}15 \\
83.30 \%\end{array}$ & $\begin{array}{c}20 \\
45.50 \%\end{array}$ & $\begin{array}{c}44 \\
50.00 \%\end{array}$ & $\begin{array}{c}79 \\
52.70 \%\end{array}$ \\
\hline Very much & $\begin{array}{c}0 \\
0.00 \%\end{array}$ & $\begin{array}{c}13 \\
29.50 \%\end{array}$ & $\begin{array}{c}30 \\
34.10 \%\end{array}$ & $\begin{array}{c}43 \\
28.70 \%\end{array}$ \\
\hline Total & $\begin{array}{c}99 \\
100 \%\end{array}$ & $\begin{array}{c}18 \\
100 \%\end{array}$ & $\begin{array}{c}44 \\
100 \%\end{array}$ & $\begin{array}{c}88 \\
100 \%\end{array}$ \\
\hline
\end{tabular}

According to the results of Table 4, there are some positive relationship between women's interests in reading novels and believing the idea of Equality of Men and Women. In other words, the more 
women believe the idea of Equality of Men and Women, the more they read novels. Therefore, we can confirm the fourth hypothesis.

\subsection{The fifth hypothesis: Reading novel and improving social skills}

The fifth hypothesis of the survey investigates whether there is any relationship between reading novel and improving social skills. Table 5 shows the results of our survey.

\section{Table 5}

The summary of the survey on relationship between improving social skills and reading novel

\begin{tabular}{|c|c|c|c|c|}
\hline \multirow{2}{*}{ Reading novel } & \multicolumn{3}{|c|}{ Leisure } & \multirow{2}{*}{ Total } \\
\hline & Little & Average & Very much & \\
\hline Little & $\begin{array}{c}0 \\
0.00 \%\end{array}$ & $\begin{array}{c}4 \\
9.10 \%\end{array}$ & $\begin{array}{c}0 \\
0.00 \%\end{array}$ & $\begin{array}{c}4 \\
2.70 \%\end{array}$ \\
\hline Average & $\begin{array}{c}10 \\
55.60 \%\end{array}$ & $\begin{array}{c}12 \\
27.30 \%\end{array}$ & $\begin{array}{c}7 \\
8.00 \%\end{array}$ & $\begin{array}{c}29 \\
19.30 \%\end{array}$ \\
\hline Very much & $\begin{array}{c}8 \\
44.40 \%\end{array}$ & $\begin{array}{c}28 \\
63.60 \%\end{array}$ & $\begin{array}{c}81 \\
92.00 \%\end{array}$ & $\begin{array}{c}117 \\
78.00 \%\end{array}$ \\
\hline Total & $\begin{array}{c}99 \\
100 \%\end{array}$ & $\begin{array}{c}18 \\
100 \%\end{array}$ & $\begin{array}{c}44 \\
100 \%\end{array}$ & $\begin{array}{c}88 \\
100 \%\end{array}$ \\
\hline
\end{tabular}

The results of Table 5 show that there were some negative relationship between improving social skills and reading novels. In other words, the more women believe improving social skills, the less they are interested in reading novels. Therefore, we can confirm the fifth hypothesis.

\subsection{The sixth hypothesis: Reading novel and women are hero}

The sixth hypothesis of the survey investigates whether there is any relationship between reading novel and believing that women are hero. Table 6 shows the results of our survey.

\section{Table 6}

The summary of the survey on relationship between believing women are hero and reading novel

\begin{tabular}{|c|c|c|c|c|}
\hline \multirow{2}{*}{ Reading novel } & \multicolumn{3}{|c|}{ Leisure } & \multirow{2}{*}{ Total } \\
\hline & Little & Average & Very much & \\
\hline Little & $\begin{array}{c}0 \\
0.00 \%\end{array}$ & $\begin{array}{c}4 \\
9.10 \%\end{array}$ & $\begin{array}{c}0 \\
0.00 \%\end{array}$ & $\begin{array}{c}4 \\
2.70 \%\end{array}$ \\
\hline Average & $\begin{array}{c}10 \\
55.60 \%\end{array}$ & $\begin{array}{c}12 \\
27.30 \%\end{array}$ & $\begin{array}{c}7 \\
8.00 \%\end{array}$ & $\begin{array}{c}29 \\
19.30 \%\end{array}$ \\
\hline Very much & $\begin{array}{c}8 \\
44.40 \%\end{array}$ & $\begin{array}{c}28 \\
63.60 \%\end{array}$ & $\begin{array}{c}81 \\
92.00 \%\end{array}$ & $\begin{array}{c}117 \\
78.00 \%\end{array}$ \\
\hline Total & $\begin{array}{c}99 \\
100 \%\end{array}$ & $\begin{array}{c}18 \\
100 \%\end{array}$ & $\begin{array}{c}44 \\
100 \%\end{array}$ & $\begin{array}{c}88 \\
100 \%\end{array}$ \\
\hline
\end{tabular}

Chi-Square=35.2 df=4 Sig. $=0.001 \quad$ Kendall's tau-b=0.4

As we can see from the results of Table 6, there are some positive relationships between believing that women are hero and reading novels. In other words, the more women believe that women are hero, the more they read novels. Therefore, we can confirm the sixth hypothesis.

\subsection{The seventh hypothesis: Reading novel and educational background}

The seventh hypothesis of the survey investigates whether there is any relationship between reading novel and educational background. Table 7 shows the results of our survey. As we can see from the results of Table 7, there are some negative relationships between educational background and reading novels. In other words, the more women are educated, the less they read novels. Therefore, we can confirm the seventh hypothesis. 


\section{Table 6}

The summary of the survey on relationship between educational background and reading novel

\begin{tabular}{|c|c|c|c|c|}
\hline \multirow{2}{*}{ Reading novel } & \multicolumn{3}{|c|}{ Leisure } & \multirow{2}{*}{ Total } \\
\hline & Little & Average & Very much & \\
\hline Little & $\begin{array}{c}4 \\
9.80 \%\end{array}$ & $\begin{array}{c}7 \\
8.20 \%\end{array}$ & $\begin{array}{c}7 \\
29.20 \%\end{array}$ & $\begin{array}{c}18 \\
12.00 \%\end{array}$ \\
\hline Average & $\begin{array}{c}3 \\
7.30 \%\end{array}$ & $\begin{array}{c}27 \\
31.80 \%\end{array}$ & $\begin{array}{c}14 \\
58.30 \%\end{array}$ & $\begin{array}{c}44 \\
29.30 \%\end{array}$ \\
\hline Very much & $\begin{array}{c}34 \\
82.90 \%\end{array}$ & $\begin{array}{c}51 \\
60.00 \%\end{array}$ & $\begin{array}{c}3 \\
12.50 \%\end{array}$ & $\begin{array}{c}88 \\
58.70 \%\end{array}$ \\
\hline Total & $\begin{array}{c}99 \\
100 \%\end{array}$ & $\begin{array}{c}41 \\
100 \%\end{array}$ & $\begin{array}{c}85 \\
100 \%\end{array}$ & $\begin{array}{c}24 \\
100 \%\end{array}$ \\
\hline
\end{tabular}

\subsection{The eighth hypothesis: Reading novel and age}

The eighth hypothesis of the survey investigates whether there is any relationship between reading novel and their age. Table 8 shows the results of our survey.

\section{Table 6}

The summary of the survey on relationship between age and reading novel

\begin{tabular}{|c|c|c|c|c|}
\hline \multirow{2}{*}{ Reading novel } & \multicolumn{3}{|c|}{ Leisure } & \multirow{2}{*}{ Total } \\
\hline & $<=31$ & $32-44$ & $>45$ & \\
\hline Little & $\begin{array}{c}15 \\
19.00 \%\end{array}$ & $\begin{array}{c}3 \\
6.40 \%\end{array}$ & $\begin{array}{c}0 \\
0.00 \%\end{array}$ & $\begin{array}{c}18 \\
12.00 \%\end{array}$ \\
\hline Average & $\begin{array}{c}19 \\
24.10 \%\end{array}$ & $\begin{array}{c}22 \\
46.80 \%\end{array}$ & $\begin{array}{c}3 \\
12.50 \%\end{array}$ & $\begin{array}{c}44 \\
29.30 \%\end{array}$ \\
\hline Very much & $\begin{array}{c}45 \\
57.00 \%\end{array}$ & $\begin{array}{c}22 \\
46.80 \%\end{array}$ & $\begin{array}{c}21 \\
87.50 \%\end{array}$ & $\begin{array}{c}88 \\
58.70 \%\end{array}$ \\
\hline Total & $\begin{array}{c}99 \\
100 \%\end{array}$ & $\begin{array}{c}15 \\
100 \%\end{array}$ & $\begin{array}{c}3 \\
100 \%\end{array}$ & $\begin{array}{c}0 \\
100 \%\end{array}$ \\
\hline
\end{tabular}

As we can observe from the results of Table 6, there are some positive relationships between age and reading novels. Therefore, we can confirm the eighth hypothesis.

\section{Conclusion}

In this paper, we have discussed the impact of eight different factors on reading Persian novels in Iran among women who lived in city of Tehran, Iran. The proposed study of this paper has detected that reading novels may be of interest of specific women who had some specific personal characteristics. Based on the results of our survey, there is a growing trend on reading Persian novels among women in Iranian community, which create motivation for dedicated authors to contribute more in this area.

\section{References}

Honarmand, S. (2011). The Impact of the Modernity Discourse on Persian Fiction (Doctoral dissertation, Ohio State University).

Rahimi, A., \& Ebrahimi, N. A. (2012). Lexical cohesion in English and Persian texts of novels. Mediterranean Journal of Social Sciences, 3(11), 569-577.

Ranjbar, E. (2010). Persian novels in the 60th. History of Literature (Journal of Human Sciences), 66(3), 169-188.

Nanquette, L. (2011). The Persian novel in French: A hybrid genre. Comparative Studies of South Asia, Africa and the Middle East, 31(2), 498-505.

Sojoudi, F., \& Zirahi, H. (2009). A survey of the tense of Persian verbs in Boofe Koor and Sovashoon within the tense theory of weinrich. Literary Criticism,

Zavarzadeh, M. U. (1968). The Persian short story since the second world war: An overview. The Muslim World, 58(4), 308-316. 